\title{
Compressive Neuropathy of the Ulnar Nerve in the Hypothenar Region by Lipoma: Case Report
}

\section{Neuropatia compressiva do nervo ulnar na região hipotenar por lipoma: Relato de caso}

\author{
Marcelo José Silva de Magalhães ${ }^{1,3}$ Henrique Nunes Pereira Oliva ${ }^{2}$ Bruno Lopes Nunes ${ }^{3}$ \\ ${ }^{1}$ Department of Neurosurgery, Vila da Serra Hospital, Belo Horizonte, \\ Minas Gerais, MG, Brazil \\ 2 Faculdade Pitágoras de Montes Claros, Montes Claros, Minas Gerais, \\ MG, Brazil \\ ${ }^{3}$ Hospital Aroldo Tourinho, Montes Claros, Minas Gerais, MG, Brazil \\ Address for correspondence Marcelo José Silva de Magalhães, MD, \\ MSc, Rua Francisco Versiane Ataide, 760, apartamento $n^{\circ} 1301$. \\ Montes Claros, MG, 39401-039, Brazil \\ (e-mail: marcelo7779@yahoo.com.br).
}

Arq Bras Neurocir 2020;39(1):49-53.

\begin{abstract}
Keywords

- lipoma

- neuropathy

- ulnar nerve

- soft-tissue tumor
\end{abstract}

\section{Resumo}

Palavras-chave

- lipoma

- neuropatia

- nervo ulnar

- tumor de partes moles
Lipomas are well-defined tumors of the adipose tissue that often occur in the torso or the extremities of adult patients. These tumors usually develop painlessly and insidiously, but they may compress adjacent structures. The objective of the present study is to describe the case of a 68-year-old female patient with a giant lipoma located at the hypothenar region, with manifestation of compression of the common palmar digital nerves, the ulnar nerve, and the abductor muscle of the $V$ finger. Regarding the symptoms, the patient felt moderate pain in the hypothenar region, with no Tinel sign, and no changes in the motor function or sensibility of the digits innervated by the ulnar nerve. Lipomas may present a varied range of histological characteristics, and malignant tumors may be a differential diagnosis. An imaging exam may aid in the diagnosis, which is confirmed by a histopathological study. For the present case, as recommended in the literature, a surgical procedure was performed for the resection of the tumor, which resulted in the control of the symptoms.

Lipomas são tumores bem definidos, de tecido adiposo, presentes no tronco ou nas extremidades, e que ocorrem em pacientes adultos. Esses tumores geralmente se desenvolvem sem dor e de forma insidiosa, podendo, no entanto, comprimir estruturas adjacentes. $O$ presente trabalho objetiva descrever o caso de uma paciente do sexo feminino, de 68 anos, com lipoma gigante localizado na face hipotenar, com manifestação de compressão dos nervos digitais palmares comuns, do nervo ulnar, e do músculo abdutor do $V$ dedo. Como sintoma, ela apresentava quadro de dor moderada na face hipotenar, sem sinal de Tinel, e sem alterações da motricidade ou sensibilidade dos dígitos inervados pelo nervo ulnar. Os lipomas podem apresentar uma variada gama de características histológicas, e o diagnóstico diferencial pode incluir tumores malignos. O exame de imagem pode auxiliar no diagnóstico, o qual é confirmado por meio de estudo histopatológico. Para o presente caso, conforme preconizado na literatura, foi realizado um procedimento cirúrgico para a ressecção do tumor, que resultou no controle dos sintomas. received

September 12, 2017

accepted

December 4, 2017
DOI https://doi.org/

10.1055/s-0038-1623517. ISSN 0103-5355.
Copyright $(2020$ by Thieme Revinter

Publicações Ltda, Rio de Janeiro, Brazil
License terms

(ㄷ) (i) $\ominus$ (5) 


\section{Introduction}

Lipomas usually present in adults as isolated tumors, with no presence of pain and with slow growth, more frequently in the thorax and extremities. ${ }^{1}$ Lipomas are typically lobular and well-circumscribed, consisting of adipose tissue cells. They are separated from the surrounding adipose tissue by a thin fibered capsule. ${ }^{1-3}$ Complementary exams are important because they assist in the determination of the type and location of the lipoma. ${ }^{4}$ Lipomas can be classified as intramuscular, more frequent, and intermuscular, less frequent. In addition, intramuscular lipomas are divided into infiltrative and well-circumscribed. ${ }^{2}$ Lipomas are commonly isolated and rarely multiple, presenting in varying shapes and sizes, being considered giant when its diameter exceeds $5 \mathrm{~cm}^{2,3}$

The present work aims to describe the rare case of intermuscular lipoma in the left upper limb hypothenar region with ulnar nerve compression. We also provide a brief bibliographic review on the subjects involved in the studied case. For this, we used recent material available in virtual libraries, in addition to analyzing the medical records of the patient with unusual case presentation.

First, a review of the medical records of the patient was carried out to elaborate the case report. Then, a bibliographic research was conducted in the literature, seeking papers published in the last 47 years, in Portuguese, English and Spanish. The inclusion criteria of the researched studies were: the appropriate methodology applied, the update, and the similarity in some aspect with the present case. Exclusion criteria were: low relevance of some articles, nonapproach to the area of interest, and lack of important information.

The following descriptors were used: lipoma, deepseated lipoma, lipomatous tumor, liposarcoma, lipoma of the extremities and intramuscular lipoma. The digital libraries and open access electronic data sources accessed were the Scienific Electronic Library Online (SciELO) and the Virtual Health Library (VHL). The portal minhaUFMG was also used to access paid articles and a theme pertinent to this research.

\section{Case Report}

Patient M. A. O., 68 years old, female, housewife, sought outpatient medical care due to persistent headache. In her physical examination, it was detected a bulging area in the hypothenar region of the left upper limb extremity. No cyanosis or phlogistic signs were observed in the bulging region. The patient reported moderate-intensity pain in the left-hand thenar region, with irradiation to digits IV and V. No Tinel sign was found on the tumor lesion, and there were no sensitivity or motricity deficits identified.

A hand ultrasonography was requested, which evidenced an echogenic nodular well-defined image, without flow to the Doppler, encapsulated, measuring $24 \mathrm{~mm}$, in the hypothenar region (-Fig. $\mathbf{1}$ ).

Upon presentation of the examination, we opted for hospitalization, which was preceded by the request for surgical risk exams. Local anesthesia was used with lidocaine

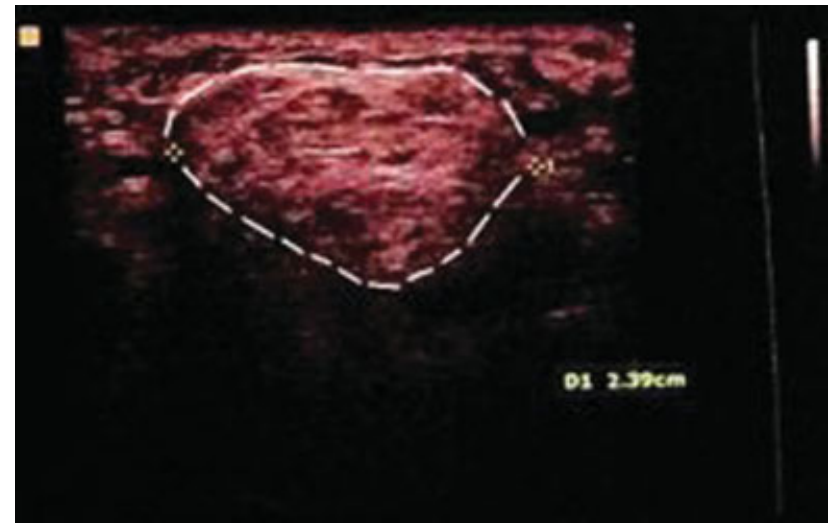

Fig. 1 Left hand ultrasonography evidencing a well-defined echogenic nodular image, without flow to the Doppler, encapsulated, measuring $2.39 \mathrm{~mm}$, in the hypothenar region. Note the dashed lines skirting the lipoma.

without vasoconstrictor medication. As surgical access, we opted for linear incision in the V-digit axis, in the hypothenar region. Neurostimulation was performed during the procedure, in order to preserve the distal motor branches of the ulnar nerve. The lesion had a relatively well-delimited capsular structure, with a slightly oval shape and yellowish staining (-Figs. 2a and $\mathbf{2 b}$ ). After complete removal of the lesion, the common palmar digital nerves of the ulnar nerve and the abductor muscle of the $\mathrm{V}$ finger were identified. In the postoperative care, the patient presented pain improvement in the hypothenar region, and preservation of the motor function was confirmed.

The evaluation of the histopathologic sections of the tissue showed a benign neoplasia consisting of $12 \mathrm{~g}$ of unilocular mature adipose tissue ( - Fig. 3a), with the pres-

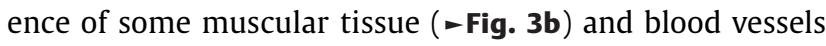
( - Fig. $3 c$ ), interwoven by connective tissue with collagen fibers (-Fig. 3d) and fibroblasts, sometimes constituting a myxoid aspect. In addition, the absence of atypia and of signs of malignancy was observed.

\section{Discussion}

Lipoma is described as a benign adipose tumor, separated from the adjacent adipose tissue by a thin, well-circumscribed, well-defined film, that can occur in any region of

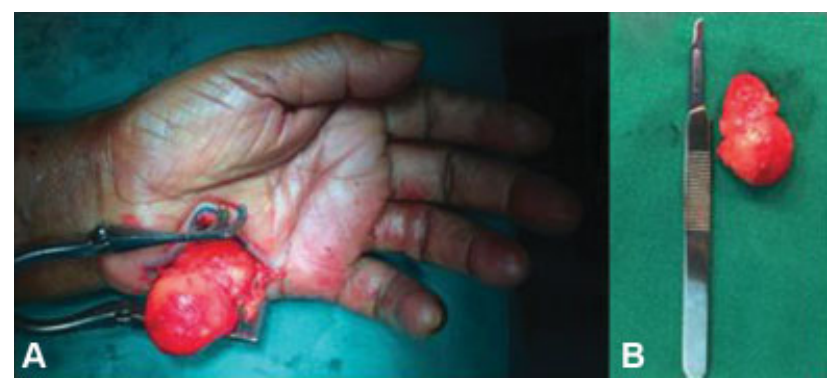

Fig. 2 (a) Perioperative photo showing voluminous lesion with a relatively well-delimited capsular structure, with slightly oval shape, and yellowish staining. (B) Photography of the lesion after its resection, confirming its oval and capsulated form. 


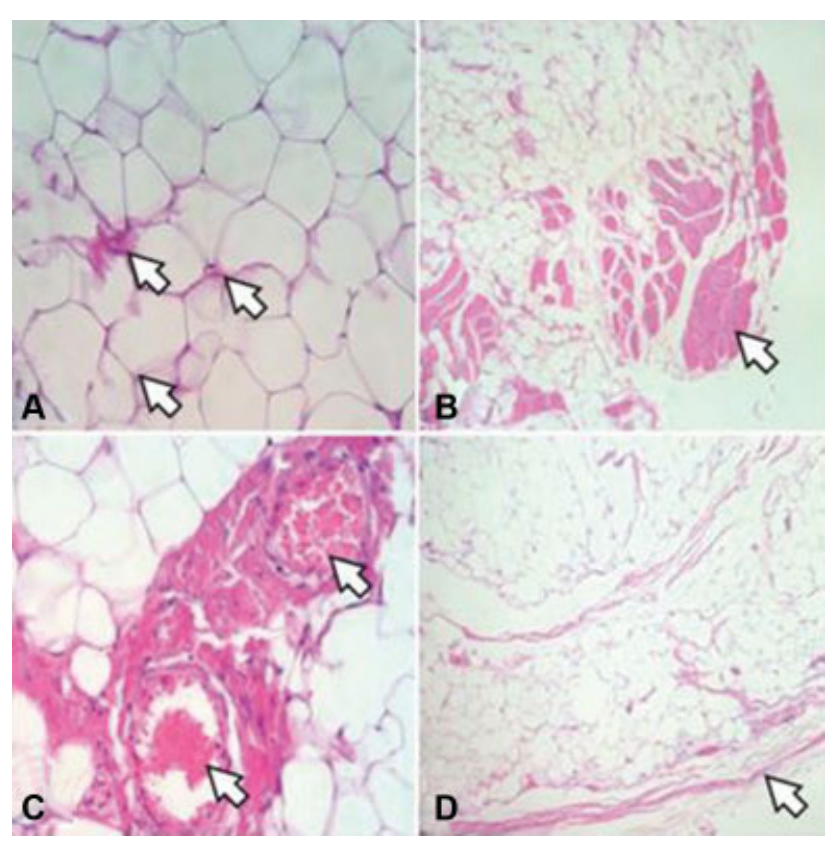

Fig. 3 Pictures of histological sections used for pathological study (Hematoxylin-eosin, enlargement x250). (A) Adipocytes with nuclear hyperchromatism (arrows) in medium to mature lipomatous background. (B) presence of muscle tissue (arrow). (C) blood vessels (arrows). (D) fibrated capsule (arrow). the body. When poorly circumscribed and very infiltrated, it can be mistaken for well-differentiated liposarcoma. Welldifferentiated liposarcomas, in turn, do not cause metastases, and they are considered of low degree of malignancy, but they present high recurrence rates. ${ }^{5,6}$

Among the main symptoms and signs of lipomas located in the hand are: local pain, paresis, hypoesthesia and local bulging by tumor growth in the underlying tissues (-Table 1). .,6 $^{5}$

The best form of treatment for lipomatous tumors is complete surgical resection. Surgery should be performed after complementary exams that allow the surgeon to locate the tumor and plan their approach, since precipitated measures may contribute to the recurrence of the tumor if it is not properly removed during surgery. ${ }^{5}$ Although surgery is commonly indicated, there is little consensus on which is the best surgical treatment for deep lipomatous tumors. ${ }^{5,7}$ In the literature, in the case of suspicion of malignancy, the wide resection, with margins of $\sim 1 \mathrm{~cm}$, associated with annual follow-up with complementary imaging examination, is presented. ${ }^{7}$

Lipomas can be commonly visualized in ultrasound as distinct echogenic masses, having a varied reading; they may be: hyperechoic (20-52\%), isoechoic (28-60\%) or hypoechoic $(20 \%){ }^{8-10}$ When encapsulated, the capsule may be difficult to identify in this imaging examination mode. ${ }^{11}$ In computed tomography (TC), lipomas are hypodense $(\sim 65,120$ units

Table 1 Case reports of hand lipomas and summary of the main clinical findings ${ }^{18-28}$

\begin{tabular}{|c|c|c|c|c|c|}
\hline Authors & Year & $n$ & Tumor localization & Symptoms & Result of Surgical care \\
\hline Rodriguez et al $^{18}$ & 1970 & 15 & 12 in the hand and 3 on the wrist. & $\begin{array}{l}14 \text { Asymptomatic tumors; } 1 \text { with } \\
\text { pain; Limitation of movement. }\end{array}$ & $\begin{array}{l}\text { Absence of recurrences and } \\
\text { complications. }\end{array}$ \\
\hline Ceballos et al $^{19}$ & 2005 & 4 & $\begin{array}{l}2 \text { in the hand ( } 1 \text { in the palmar space, } \\
1 \text { in the thenar eminence) and } 2 \text { in } \\
\text { the fingers. }\end{array}$ & Swelling and aesthetic discomfort. & $\begin{array}{l}\text { Postoperatory period without } \\
\text { intercurrences. No complications. }\end{array}$ \\
\hline Kamath et $\mathrm{al}^{20}$ & 2006 & 1 & Palmar region. & $\begin{array}{l}\text { Swelling and discomfort for } \\
\text { movement. }\end{array}$ & $\begin{array}{l}\text { Recovery of the function and without } \\
\text { recurrences. }\end{array}$ \\
\hline Mohan et $\mathrm{al}^{21}$ & 2008 & 1 & Between the thenar muscles. & $\begin{array}{l}\text { Some difficulty in the seizure of } \\
\text { objects (by important bulging). }\end{array}$ & Recovery of hand function. \\
\hline Nadar et al ${ }^{22}$ & 2010 & 13 & $\begin{array}{l}13 \text { in the hand ( } 5 \text { on the back, } 6 \\
\text { palmar, } 1 \text { on the wrist) and } 1 \text { on the } \\
\text { forearm. }\end{array}$ & Bulging, pain, paresis and pruritus. & $\begin{array}{l}\text { Remission of the feel-but. No recur- } \\
\text { rences were found. }\end{array}$ \\
\hline Pagonis et $\mathrm{al}^{23}$ & 2011 & 1 & Palmar region. & $\begin{array}{l}\text { Compression of the median and } \\
\text { ulnar nerves characteristic } \\
\text { symptoms; Reduction of pulse } \\
\text { movement amplitude; flexion } \\
\text { limitation of the distal phalanx } \\
\text { (I finger). }\end{array}$ & $\begin{array}{l}\text { Remission of pain and recovery of } \\
\text { motricity. }\end{array}$ \\
\hline Chatterton et $\mathrm{al}^{24}$ & 2013 & 1 & Thenar eminence. & $\begin{array}{l}\text { Left thumb pain and swelling in the } \\
\text { hand. }\end{array}$ & $\begin{array}{l}\text { After excision of the lipoma, the } \\
\text { patient went through a trapezectomy } \\
\text { to treat arthritis of the carpometacar- } \\
\text { pal joints. }\end{array}$ \\
\hline Ramirez et al ${ }^{25}$ & 2013 & 1 & Third finger of the left hand. & $\begin{array}{l}\text { Limitation of interphalangeal } \\
\text { movement and digital paresthesia. }\end{array}$ & $\begin{array}{l}\text { Complete motricity recovery and } \\
\text { disappearance of paresthesia. }\end{array}$ \\
\hline Radivojcevic et al ${ }^{26}$ & 2016 & 1 & $\begin{array}{l}\text { Ulnar region of the palm of the } \\
\text { hand. }\end{array}$ & $\begin{array}{l}\text { Pain and tingling in the fingers } \\
\text { (IV and V). }\end{array}$ & Pain control. \\
\hline Schmidt $^{27}$ & 2017 & 1 & $\begin{array}{l}\text { Thenar region with extension to } \\
\text { fingers. }\end{array}$ & $\begin{array}{l}\text { Limitation of finger extension (I-III), } \\
\text { paresthesia and pain. }\end{array}$ & $\begin{array}{l}\text { Six months after surgery, function and } \\
\text { sensitivity of the affected fingers were } \\
\text { restored. }\end{array}$ \\
\hline Ribeiro et $\mathrm{al}^{28}$ & 2017 & 1 & Palmar region. & $\begin{array}{l}\text { Paresthesia and pain in the } \\
\text { fingers (I-III). }\end{array}$ & $\begin{array}{l}\text { Reversal of the complaints of } \\
\text { paresthesia and pain. }\end{array}$ \\
\hline
\end{tabular}


Hounsfield). ${ }^{10,11}$ Magnetic resonance imaging (MRI) is often the modality of choice in the case of lipomas, not only to confirm diagnosis, which is usually suggested by ultrasound and TC, as well as better evaluating the atypical features suggesting the diagnosis of liposarcoma. In MRI, lipomas show hyperintense in sequences T1 and T2. Furthermore, magnetic resonance imaging allows a better definition of the anatomy adjacent to the tumor. ${ }^{11}$

The histological aspect of lipomas is characteristic, with predominant amount of adipose tissue, with adipocytes and negative image of fat. There is also the frequent presence of a fibered capsule involving the superficial region of the tumor. $^{1}$ Less often, blood vessels are observed, often more abundant in the surrounding muscle tissue than in the tumor region, being muscular capillaries. ${ }^{1,8}$ In addition, there is a beam of muscular fibers in the middle of the tumor tissue. $^{8}$

Despite the range of possibilities for histological tissue types, which may vary from benign lipomas to liposarcomas, it is estimated that lipomatous neoplasms comprise half of all soft tissue tumors. ${ }^{1,5}$ Due to eventual similarities between benign and malignant affections, histological analyses have been conducted, and studies report some characteristics that allow the physician to assist in the correct diagnosis and in the efficient referral to appropriate treatment. Advanced age, tumor of high dimensions, and localization at the extremity instead of the thorax, for example, are characteristics that suggest an atypical lipomatous tumor, instead of a giant lipoma. $^{5}$

There are other types of lesions of a benign character that can be considered as a differential diagnosis in the present case. The importance of mentioning these tumors found in the hand is due to the complexity of the affected structures and, consequently, the implications, such as loss of sensitivity, pain or even motor impairment of the limb. ${ }^{12}$ In the group of lesions that could be differential diagnosis are: synovial cyst, giant cell tumor of the tendon sheath, cysts of epidermal inclusion, fibromas, Schwannomas and neurofibromas. ${ }^{12-17}$

A table was elaborated relating rare and representative lipoma cases (-Table 1). Most of them present mild symptomatology and/or presence of local bulging without symptoms. Rare cases developed with neurological manifestations, and all revealed resolution of the pain and motor symptoms when present. ${ }^{18-28}$

\section{Conclusion}

The presence of lipoma in the hand, besides being uncommon, may not generate early clinical manifestations until the tumor reaches a larger volume and compresses the adjacent structures. The surgical procedure corroborates the effectiveness reported in the literature, being the recommended conduct. Due to the existence of lesions of different natures that may compromise the hand, surgery also allows obtaining material for histopathological confirmation.

\section{Conflict of Interests}

The authors have no conflict of interests to declare.

\section{References}

1 Errani C, Cocchi S, Ali N, et al. Recurrence after marginal excision for atypical lipomatous tumors versus lipomas of the extremities. Orthopedics 2016;39(04):e610-e614

2 Elbardouni A, Kharmaz M, Salah Berrada M, Mahfoud M, Elyaacoubi M. Well-circumscribed deep-seated lipomas of the upper extremity. A report of 13 cases. Orthop Traumatol Surg Res 2011; 97(02):152-158

3 Ramos-Pascua LR, Guerra-Álvarez OA, Sánchez-Herráez S, Izquierdo-García FM, Maderuelo-Fernández JA. [Intramuscular lipomas: Large and deep benign lumps not to underestimated. Review of a series of 51 cases]. Rev Esp Cir Ortop Traumatol 2013; 57(06):391-397

4 Jones AP, Lewis CJ, Dildey P, Hide G, Ragbir M. Lipoma or liposarcoma? A cautionary case report. J Plast Reconstr Aesthet Surg 2012;65(01):e11-e14

5 Fisher SB, Baxter KJ, Staley CA III, et al. The General Surgeon's quandary: atypical lipomatous tumor vs lipoma, who needs a surgical oncologist? J Am Coll Surg 2013;217(05):881-888

6 Dalal KM, Antonescu CR, Singer S. Diagnosis and management of lipomatous tumors. J Surg Oncol 2008;97(04):298-313

7 Kito M, Yoshimura Y, Isobe K, et al. Clinical outcome of deepseated atypical lipomatous tumor of the extremities with median-term follow-up study. Eur J Surg Oncol 2015;41(03):400-406 (EJSO)

8 Kindblom LG, Angervall L, Stener B, Wickbom I. Intermuscular and intramuscular lipomas and hibernomas. A clinical, roentgenologic, histologic, and prognostic study of 46 cases. Cancer 1974;33 (03):754-762

9 Cappabianca S, Colella G, Pezzullo MG, et al. Lipomatous lesions of the head and neck region: imaging findings in comparison with histological type. Radiol Med (Torino) 2008;113(05):758-770

10 Inampudi P, Jacobson JA, Fessell DP, et al. Soft-tissue lipomas: accuracy of sonography in diagnosis with pathologic correlation. Radiology 2004;233(03):763-767

11 Murphey MD, Carroll JF, Flemming DJ, Pope TL, Gannon FH, Kransdorf MJ. From the archives of the AFIP: benign musculoskeletal lipomatous lesions. Radiographics 2004;24(05): 1433-1466

12 Henderson MM, Neumeister MW, Bueno RA Jr. Hand tumors: I. skin and soft-tissue tumors of the hand. Plast Reconstr Surg 2014; 133(02):154e-164e

13 Weisstein JS, Trumble TE, Budoff JE. Benign and malignant bone tumors. Hand Surgery Updates IV. American Society for Surgery of the Hand, Rosemont, USA; 2007

14 Adams EL, Yoder EM, Kasdan ML. Giant cell tumor of the tendon sheath: experience with 65 cases. Eplasty, v. 12, 2012

15 Nahra ME, Bucchieri JS. Ganglion cysts and other tumor related conditions of the hand and wrist. Hand Clin 2004;20(03):249$-260, v$

16 Forthman CL, Blazar PE. Nerve tumors of the hand and upper extremity. Hand Clin 2004;20(03):233-242, v

17 Magalhães MJS, Fujioka AJ, Chaves RB. Schwannoma como etiologia de síndrome do túnel do carpo - relato de caso. Arq Bras Neurocir 2015;34(04):309-312

18 Rodriguez JM, Phalen GS. Lipomas in the hand and wrist; diagnosis and treatment. Cleve Clin Q 1970;37(04):201-205

19 Ceballos JIG, Wylock P. Hand palm and finger lipomas: four case reports and review of the literature. Eur J Plast Surg 2005;28(03): 243-246

20 Kamath J, Kamath R, Bhardwaj P, Sharma C. A giant lipoma in the hand-report of a rare case. J Health Allied Sci 2006;5(01):1-6 
21 Mohan L, Semoes J. Thenar intramuscular lipoma: an unusual case. Internet J Surg 2008;17(02):1-3

22 Nadar MM, Bartoli CR, Kasdan ML. Lipomas of the hand: a review and 13 patient case series. Eplasty 2010;10:e66

23 Pagonis T, Givissis P, Christodoulou A. Complications arising from a misdiagnosed giant lipoma of the hand and palm: a case report. J Med Case Reports 2011;5(01):552

24 Chatterton BD, Moores TS, Datta P, Smith KD. An exceptionally large giant lipoma of the hand. BMJ Case Rep 2013;2013:bcr2013200206

25 Ramirez-Montaño L, Lopez RP, Ortiz NS. Giant lipoma of the third finger of the hand. Springerplus 2013;2(01):164
26 Radivojcevic UM, Ilic M, Vulovic D. Giant hand lipoma-Case report of a rare localization of a common type of tumor. Sanamed 2016; 11(02):141-144

27 Schmidt I. Giant Lipoma of the Thenar leading to Entrapment of All Peripheral Long Finger Branches of the Median Nerve: Case Report. JSM Clin Case Rep 2017;5(01):1125

28 Ribeiro G, Salgueiro M, Andrade M, Fernandes VS. Giant palmar lipoma - an unusual cause of carpal tunnel syndrome. Rev Bras Ortop 2017;52(05):612-615 